\title{
Control of Hypertension by Verapamil Enhances Renal Damage in a Rat Remnant Kidney Model
}

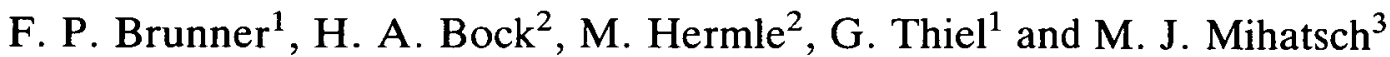 \\ Departments of ${ }^{1}$ Internal Medicine, ${ }^{2}$ Research and ${ }^{3}$ Pathology, University of Basel, $\mathrm{CH}-4031$ Basel, Switzerland
}

\begin{abstract}
The effect of calcium channel blockers on the progression of renal failure is controversial. In contrast with earlier studies, we recently reported that moderately large doses of verapamil significantly accelerated chronic renal failure in the rat remnant kidney model [1]. Studies reporting beneficial effects of verapamil were characterised by a much lower dose of verapamil and by the start of treatment immediately after renal ablation, which potentially interfered with the initial phase of remnant kidney hypertrophy. We therefore studied the effects of a high, fully antihypertensive oral dose of verapamil (100-150 mg/kg/per day; group Vera high) and a low, haemodynamically almost ineffective dose $(10-15 \mathrm{mg} / \mathrm{kg}$ per day; group Vera low), on the progression of chronic renal failure in female Wistar rats with $5 / 6$ nephrectomy. The treatment was started no earlier than 5 weeks after renal ablation, and matched groups of 20 animals were followed for 16 weeks thereafter. High-dose verapamil reduced systolic blood pressure to median values of $130-140 \mathrm{mmHg}$ throughout the experimental period, whereas blood pressure in Vera low animals remained elevated at median values of $165-172 \mathrm{mmHg}$ similar to non-treated rats with 172-185 mmHg median systolic blood pressure.

Despite control of hypertension, proteinuria increased more rapidly and to more elevated values in the Vera high animals $(5.98 \pm 0.91 \mathrm{mg} / \mu \mathrm{mol}$ creatinine before death/sacrifice) than in the Vera low and control groups $(3.08 \pm 0.91$ and $3.60 \pm 0.71 \mathrm{mg} / \mu \mathrm{mol}$ creatinine, respectively, $P<0.05$ vs Vera high), and signifi-
\end{abstract}

Correspondence and offprint requests to: Professor F. P. Brunner, Kantonsspital Basel, 4031 Basel, Switzerland. cantly more animals died during the observation period in the Vera high compared to the control group (6 of 20 vs 1 of $20, P<0.05$ ). Kidney remnants were larger in the Vera high group, mainly due to tubulointerstitial changes with filling of dilated tubular lumina with proteinaceous casts. Mean glomerular diameter did not differ between groups, and the percentage of glomeruli with segmental or global glomerulosclerosis was not significantly increased in the Vera high group.

It is concluded that chronic high-dose verapamil therapy in the 5/6 nephrectomy model, albeit effective in controlling hypertension, is deleterious to renal function when remnant hypertrophy has previously been allowed to occur. A low, haemodynamically barely effective, dose of verapamil fails to alter the course of renal failure in this setting.

Key words: Calcium channel blocker; Glomerulosclerosis; Rat remnant kidney; Verapamil

\section{Introduction}

Antihypertensive therapy has been shown to retard progressive chronic renal failure in various rat models of experimental renal disease [1-6] and also in humans with diabetic nephropathy $[7,8]$ as well as other primary renal diseases [9-11]. However, in the most extensively studied model of chronic renal failure, the remnantkidney rat, the response to different antihypertensive regimens is not uniform. Control of hypertension by 
ACE inhibitors has proven to be superior to triple-drug therapy with hydralazine, reserpine, and hydrochlorothiazide regarding prevention or delay in progressive glomerulosclerosis [12], and the highly protective effect of ACE inhibitors was invariably associated with greatly reduced proteinuria $[1,12,13]$.

In contrast to the clear-cut beneficial effects of $\mathrm{ACE}$ inhibitors, studies with calcium channel blocking agents have yielded conflicting results. Harris et al [14] injected a small dose of twice $0.1 \mathrm{mg} / \mathrm{kg}$ verapamil daily. Although lacking any antiproteinuric or antihypertensive action, this small dose of verapamil prolonged survival when applied to male Wistar rats starting 1 week after renal ablation. Eliahou et al [15] administered nisoldipine starting immediately after renal ablation, which prevented hypertension, had little effect on proteinuria, but improved survival in male and female Charles River rats. These reports of beneficial effects of calcium antagonists are at variance with studies in remnant-kidney rats performed earlier in our laboratory [1] and by Jackson et al [13]. The latter authors reported a tendency to increased proteinuria in female Sprague-Dawley rats despite excellent control of hypertension after 6 weeks of treatment with the calcium channel blocker felodipine.

In our previous study [1], verapamil at a concentration of $0.5-0.7 \mathrm{~g} / \mathrm{l}$ in the drinking water starting 5 weeks after renal ablation was found to increase proteinuria, to promote glomerulosclerosis and to shorten survival in female Wistar rats. However, the amount of verapamil consumed from the drinking water failed to reduce the elevated blood pressure reliably because it fell short of $100 \mathrm{mg} / \mathrm{kg}$ per day in many animals. The present study was therefore undertaken to compare the outcome in remnant-kidney rats receiving a fully antihypertensive dose of $100-150 \mathrm{mg} / \mathrm{kg}$ oral verapamil daily [16] to another group receiving the relatively low dose of $10-15$ $\mathrm{mg} / \mathrm{kg}$ per day of oral verapamil.

\section{Methods}

Renal ablation was performed in a total of 100 female Wistar rats over a 4 week period. Once weekly a group of 25 animals weighing $110-130 \mathrm{~g}$ was subjected to partial infarction of the left kidney as previously described [1]. In short, 2-3 upper branches of the left renal artery were tied off, followed by right nephrectomy 1 week later. Another 5 weeks later, the rats were placed in individual metabolic cages for 2 days. The 24-h urine of the second day was used to determine proteinuria and creatinine excretion. Blood was obtained from the cut end of the tail. Arterial blood pressure was measured by tail plethysmography in the awake animals. Since the range of the plethysmograph used did not exceed
$200 \mathrm{mmHg}$, pressures over 200 were recorded as '205' $\mathrm{mmHg}$ for non-parametric statistical evaluation. Of each group of 25 rats, five triplets with similar degree of proteinuria and hypertension were selected, while the remaining ten rats were excluded from further study. One rat of each triplet was then allocated at random to one of the two experimental groups and the control group. We thus obtained four subgroups of five animals in each of the experimental and the control groups. These subgroups were housed in group cages with tap water ad lib. The animals were offered $14 \mathrm{~g} / \mathrm{rat}$ per day of a standard ground rat diet (Klingentalmühle $A G$, Basel) containing 30\% protein (casein IA) and $20 \mathrm{mmol}$ $\mathrm{NaCl}$ per $\mathrm{kg}$ food. Left-over food was weighed. Commencing 5 weeks and a few days after nephrectomy, one group of 20 rats (Vera high) received verapamil in concentrations of $1.43 \mathrm{~g} / \mathrm{kg}$ food and $250 \mathrm{mg} / \mathrm{l} \mathrm{drinking}$ water. This was intended to result in an oral verapamil intake of $100-150 \mathrm{mg} / \mathrm{kg}$ rat (each animal receiving 20 $\mathrm{mg}$ in the daily food allowance of $14 \mathrm{~g}$ and 5-10 $\mathrm{mg}$ with the drinking water). The second group (Vera low) received one-tenth of this dose $(0.143 \mathrm{~g} / \mathrm{kg}$ food and 25 $\mathrm{mg} / \mathrm{l}$ drinking water). Every 4 weeks, the animals were placed into the metabolic cages for 2 days to determine proteinuria and creatinine clearance followed by plethysmographic measurement of blood pressure in the afternoon of the third day.

Treatment was carried on for a total of 16 weeks unless the animals had to be killed earlier because they developed uraemic symptoms such as decreased food intake, weight loss and listlessness, and looked sick and miserable. At the end of the experimental period, mean arterial blood pressure and heart rate were measured: the animals received inactin $50-90 \mathrm{mg} / \mathrm{kg}$ i.p. and were placed on a heated animal board to keep rectal temperature between 37 and $38^{\circ} \mathrm{C}$. A polyethylene cannula was then placed in the left carotid artery and connected to a Statham transducer with a Hellige recorder. After obtaining stable readings for heart rate and blood pressure for at least $10 \mathrm{~min}$, the animals were exsanguinated for determination of blood chemistry and the heart and kidney were removed and weighed.

A Beckman creatinine analyser was used to measure creatinine in plasma and urine, and the central hospital laboratories' multichannel Hitachi analyser for determining creatinine, urea, electrolytes, and lipids at sacrifice. Plasma albumin was measured colorimetrically with bromcresol green [17]. Urinary protein content was determined by tannic acid precipitation with $\mathrm{Fe}^{3+}$ colorimetry as described by Yatzidis [18]. Proteinuria was expressed as $\mathrm{mg}$ protein excreted per $\mu \mathrm{mol}$ creatinine. For histological examination, the kidneys were fixed in phosphate-buffered $4 \%$ formalin. Three $\mu \mathrm{m}$ sections were stained with $\mathrm{H} \& \mathrm{E}, \mathrm{PAS}$, periodic acid/ silver methenamine, and chromotrope aniline-blue. 
One hundred glomeruli were examined in each kidney for the presence or absence of segmental or global glomerular sclerosis. Care was taken to evaluate renal histology in intact parts of the remnant kidneys outside of scarred regions close to infarcted areas. Mean glomerular diameter for each kidney was calculated from 15 to 40 individual non-sclerosed glomerular crosssectional areas using the graphic tablet cursor (Kontron München). The pathologist (M. J. Mihatsch) evaluated renal histology without knowledge of the treatment the rats had received.

Results are expressed either as means $\pm \mathrm{SEM}$, or as medians and range. Mann-Whitney's U-test, Fisher's exact test, and the Spearman rank correlation were used for statistical evaluation as appropriate.

\section{Results}

As described previously [1], our technique of tying off 2-3 upper branches of the left renal artery combined with contralateral nephrectomy resulted in an at least $4 / 5$ reduction of renal mass. No drugs were given for 5 weeks after nephrectomy to allow undisturbed hypertrophy of the kidney remnants and growth of the animals. They had thus reached body weights of 170 $200 \mathrm{~g}$ when the control and the two experimental groups were formed. Animals with similar degrees of hypertension and proteinuria were allocated to the three groups, as reflected by the homogeneous baseline values for creatinine clearance, proteinuria, and systolic blood pressure (Tables 1 and 2).

Table 1. Renal function and proteinuria before commencing verapamil

\begin{tabular}{lccc}
\hline & $\begin{array}{l}\text { Control } \\
(n=20)\end{array}$ & $\begin{array}{l}\text { Vera low } \\
(n=20)\end{array}$ & $\begin{array}{c}\text { Vera high } \\
(n=20)\end{array}$ \\
\hline $\mathrm{P}_{\mathrm{Cr}}(\mu \mathrm{mol} / \mathrm{l})$ & $71 \pm 3$ & $69 \pm 3$ & $73 \pm 3$ \\
$\mathrm{C}_{\mathrm{Cr}}(\mu \mathrm{l} / \mathrm{min}$ per 100 g body-wt $)$ & $282 \pm 9$ & $279 \pm 11$ & $281 \pm 14$ \\
Proteinuria (mg $/ \mu \mathrm{mol} \mathrm{Cr})$ & $1.41 \pm 0.23$ & $1.45 \pm 0.26$ & $1.43 \pm 0.23$ \\
\hline
\end{tabular}

All values are mean \pm SEM.

In the control group a single animal developed uraemic symptoms towards the end of the experimental period and had to be sacrificed (Fig. 1). In the Vera low group, one rat died spontaneously on day 9 and a second animal had to be sacrificed on day 54 . In the Vera high group, six animals died before 16 weeks: two died spontaneously (at 61 days and at 105 days after starting high-dose verapamil treatment), the other four were sacrificed between days 53 and 87 because of uraemic symptoms such as listlessness, failure to eat, and weight loss. Their blood urea concentrations were between 63

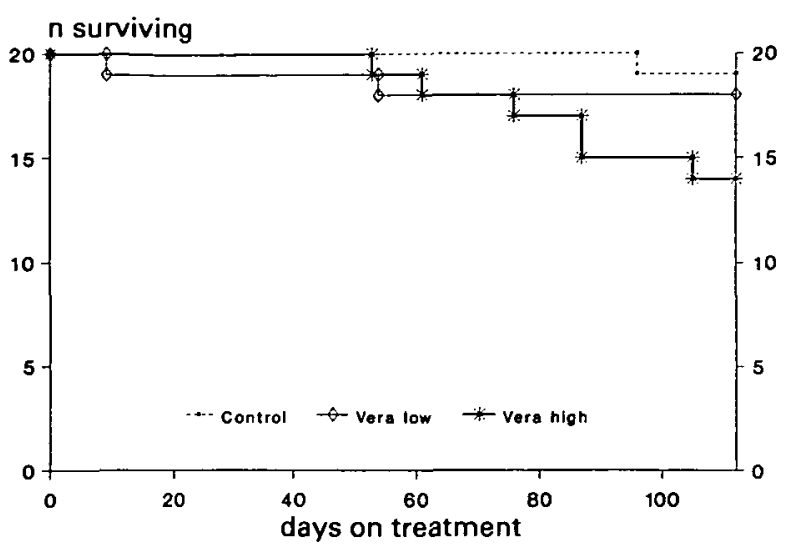

Fig. 1. Survival curve showing greater mortality in Vera high group (14 of 20 rats surviving; $P<0.05 \mathrm{v}$ control with 19 of 20 rats surviving).

and $112 \mathrm{mmol} / \mathrm{l}$. Mortality in the Vera high group (6 of 20 rats) was significantly greater than in the control group ( 1 of 20 rats, $P<0.05$, Fisher's exact test).

The surviving animals continued to grow during the treatment period. In the control group body weight increased from $192 \pm 3 \mathrm{~g}(n=20)$ to $244 \pm 5 \mathrm{~g}(n=19)$, in the Vera low group from $179 \pm 3(n=20, P<0.05$ vs control) to $228 \pm 5 \mathrm{~g}(n=18$, n.s. vs control $)$ and in the Vera high group from $184 \pm 3 \mathrm{~g}(n=20$, n.s. vs control and Vera low $)$ to $221 \pm 5 \mathrm{~g}(n=14, P<0.05$ vs control, n.s. vs Vera low).

\section{Blood Pressure}

The majority of the rats were hypertensive at the time of forming the experimental and the control groups (Table 2). High-dose verapamil (Vera high group) reduced systolic blood pressure to values well below baseline and the decrease in blood pressure persisted throughout the experimental period. The average consumption of verapamil in this group amounted to approximately $25 \mathrm{mg}$ or $130 \mathrm{mg} / \mathrm{kg}$ daily at the beginning and decreased slightly to about $110 \mathrm{mg} / \mathrm{kg}$ at the end of the experimental period as the animals gained some weight.

No effect on awake systolic blood pressure was observed in the Vera low group which received 10 to 15 $\mathrm{mg} / \mathrm{kg}$ per day of oral verapamil. In both the control and the Vera low groups, systolic blood pressure remained essentially unchanged throughout the observation period (Table 2).

\section{Proteinuria and Renal Function}

Mean values for baseline renal function and proteinuria are shown in Table 1. Creatinine clearance in surviving animals was about $50 \%$ of normal throughout the observation period and did not differ among groups. At 16 weeks, mean values were $306 \pm 20 \mu \mathrm{l} / \mathrm{min}$ per $100 \mathrm{~g}$ 
Table 2. Systolic blood pressure and proteinuria at 4 week intervals during verapamil treatment

\begin{tabular}{|c|c|c|c|c|c|c|c|}
\hline & & \multicolumn{3}{|c|}{ Systolic blood pressure (mmHg) } & \multicolumn{3}{|c|}{ Proteinuria $(\mathrm{mg} / \mu \mathrm{mol} \mathrm{Cr})$} \\
\hline & & Control & Vera low & Vera high & Control & Vera low & Vera high \\
\hline $\begin{array}{l}\text { Before treatment } \\
(n=20 / 20 / 20)\end{array}$ & $\begin{array}{l}\text { Median } \\
\text { (range) }\end{array}$ & $\begin{array}{l}172 \\
(125->200)\end{array}$ & $\begin{array}{l}170 \\
(125->200)\end{array}$ & $\begin{array}{l}165 \\
(130->200)\end{array}$ & $\begin{array}{l}1.18 \\
(0.23-4.53)\end{array}$ & $\begin{array}{l}1.18 \\
(0.22-5.45)\end{array}$ & $\begin{array}{l}1.20 \\
(0.36-4.00)\end{array}$ \\
\hline $\begin{array}{l}\text { Week } 4 \\
\qquad(n=20 / 19 / 20)\end{array}$ & $\begin{array}{l}\text { Median } \\
\text { (range) }\end{array}$ & $\begin{array}{l}175 \\
(130->200)\end{array}$ & $\begin{array}{l}165 \\
(130->200)\end{array}$ & $\begin{array}{l}140^{000 / * * *} \\
(125-160)\end{array}$ & $\begin{array}{l}0.93 \\
(0.14-4.48)\end{array}$ & $\begin{array}{l}1.56 \\
(0.27-12.9)\end{array}$ & $\begin{array}{l}1.53 \\
(0.38-11.4)\end{array}$ \\
\hline $\begin{array}{l}\text { Week } 8 \\
\quad(n=20 / 19 / 19)\end{array}$ & $\begin{array}{l}\text { Median } \\
\text { (range) }\end{array}$ & $\begin{array}{l}175 \\
(130->200)\end{array}$ & $\begin{array}{l}170 \\
(130->200)\end{array}$ & $\begin{array}{l}130000 / * * * \\
(120-160)\end{array}$ & $\begin{array}{l}1.23 \\
(0.15-7.34)\end{array}$ & $\begin{array}{l}1.80 \\
(0.21-14.7)\end{array}$ & $\begin{array}{l}2.96^{*} \\
(0.33-10.9)\end{array}$ \\
\hline $\begin{array}{l}\text { Week } 12 \\
\qquad(n=20 / 18 / 17)\end{array}$ & $\begin{array}{l}\text { Median } \\
\text { (range) }\end{array}$ & $\begin{array}{l}175 \\
(125->200)\end{array}$ & $\begin{array}{l}172 \\
(130->200)\end{array}$ & $\begin{array}{l}135000 / * * * \\
(115-180)\end{array}$ & $\begin{array}{l}1.76 \\
(0.20-8.28)\end{array}$ & $\begin{array}{l}1.73 \\
(0.27-10.9)\end{array}$ & $\begin{array}{l}3.46 \\
(0.49-14.8)\end{array}$ \\
\hline $\begin{array}{l}\text { Week } 16 \\
\quad(n=19 / 18 / 14)\end{array}$ & $\begin{array}{l}\text { Median } \\
\text { (range) }\end{array}$ & $\begin{array}{l}185 \\
(125->200)\end{array}$ & $\begin{array}{l}162 \\
(135->200)\end{array}$ & $\begin{array}{l}140^{\circ 00 / * * *} \\
(115-150)\end{array}$ & $\begin{array}{l}1.56 \\
(0.31-10.7)\end{array}$ & $\begin{array}{l}2.34 \\
(0.25-5.24)\end{array}$ & $\begin{array}{l}3.32 \\
(0.86-11.0)\end{array}$ \\
\hline
\end{tabular}

$P$ (Mann-Whitney U-test) vs control ${ }^{*}<0.05^{* * *}<0.001$, Vera high vs Vera low $\infty \infty<0.001$

rat $(n=19)$ for the control, $295 \pm 27 \mu \mathrm{l} / \mathrm{min}$ per $100 \mathrm{~g}$ rat $(n=18)$ for the Vera low, and $305 \pm 2 \mu \mathrm{l} / \mathrm{min}$ per $100 \mathrm{~g}$ rat $(n=14)$ for the Vera high group. Those rats that died or had to be sacrificed earlier, had rapidly increasing plasma creatinine to final concentrations between 144 and $295 \mu \mathrm{mol} / \mathrm{l}$.

As noted in previous studies, the range of proteinuria was extremely wide, but baseline values in the two experimental groups and the control group (Fig. 2) did not differ significantly. The extremes of 0.2 and $10 \mathrm{mg} /$ $\mu$ mol creatinine correspond to daily protein excretion rates of 6 and $300 \mathrm{mg}$ per $100 \mathrm{~g}$ body-weight.

Proteinuria increased in the majority of the animals (Fig. 2). However, there were distinct differences between groups. The median level of proteinuria increased only minimally in the control group, whereas it doubled in the Vera low group and reached three
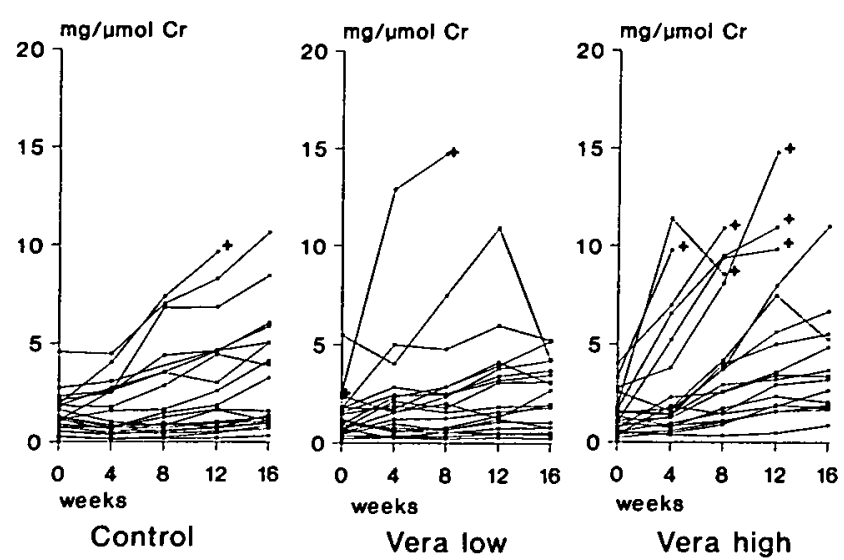

Fig. 2. Proteinuria of individual animals at $0,4,8,12$, and 16 weeks after starting treatment with verapamil. + denotes non-surviving rat. Proteinuria is shown to increase more rapidly in Vera high group compared to both Vera low group and control. times the initial value in the Vera high group (Table 2). This enhancement of proteinuria by high-dose verapamil was all the more striking as the six rats with the most rapidly increasing protein excretion rates of this group did not survive to the end of the 16 weeks' experimental period. Average proteinuria before death or sacrifice for all 20 rats in each group was significantly greater in group Vera high with $5.98 \pm 0.91 \mathrm{mg} / \mu \mathrm{mol}$ creatinine compared to Vera low with $3.08 \pm 0.70 \mathrm{mg} / \mu \mathrm{mol}$ creatinine $(P<0.02)$ and to the control group with 3.60 $\pm 0.71 \mathrm{mg} / \mu \mathrm{mol}$ creatinine $(P<0.05)$. The average slope of the increase in proteinuria was significantly greater in the Vera high than in both the Vera low group and the control group $(P<0.01$ by ANOVA).

\section{Other Observations}

Heart rate and mean arterial blood pressure measured in the survivors after 16 weeks of observation are shown in Table 3. Both were markedly lower in the Vera high group, whereas no statistically significant differences were found between the Vera low and the control group. Wet heart weights did not differ between groups despite excellent control of hypertension in the Vera high group.

Plasma albumin concentration at death or sacrifice was $33.8 \pm 0.7 \mathrm{~g} / \mathrm{l}(n=20)$ in the control group and 30.4 $\pm 0.9 \mathrm{~g} / \mathrm{l}(n=18)$ in the Vera high group $(P<0.01)$. Plasma albumin in the Vera low rats $(32.2 \pm 0.6 \mathrm{~g} / 1, n=$ 19) did not differ significantly from either the control or the Vera high group. Plasma cholesterol levels at death or sacrifice varied greatly among individul animals. The mean level was significantly lower in the Vera low group $(2.05 \pm 0.23 \mu \mathrm{mol} / \mathrm{l}, n=19)$ than in the Vera high group $(2.79 \pm 0.25 \mu \mathrm{mol} / /, n=18, P<0.01)$. The mean level 
Table 3. Mean arterial blood pressure, heart rate, heart weight, and body-weight after 16 weeks of verapamil

\begin{tabular}{|c|c|c|c|}
\hline & $\begin{array}{l}\text { Control } \\
(n=19)\end{array}$ & $\begin{array}{l}\text { Vera low } \\
(n=18)\end{array}$ & $\begin{array}{l}\text { Vera high } \\
(n=14)\end{array}$ \\
\hline Mean arterial BP $(\mathrm{mmHg})$ & $\begin{array}{l}180 \pm 8 \\
422 \pm 6\end{array}$ & $\begin{array}{l}156 \pm 7 \\
393+14\end{array}$ & $\begin{array}{l}124 \pm 3 * 0^{*} 0^{*} \\
358+6 * 6^{*} *\end{array}$ \\
\hline \multirow{3}{*}{$\begin{array}{l}\text { Heart wet weight } \\
(\mathrm{g} / 100 \mathrm{~g} \text { body-wt) } \\
\text { Body weight }(\mathrm{g})\end{array}$} & & & \\
\hline & $0.32 \pm 0.01$ & $0.34 \pm 0.01$ & $0.35 \pm 0.01$ \\
\hline & $244 \pm 5$ & $228 \pm 5$ & $221 \pm 5^{*}$ \\
\hline
\end{tabular}

All values are mean $\pm S E M$.

$P$ (Mann-Whitney U-test) vs control ${ }^{*}<0.05^{* * *}<0.001$

Vera high vs Vera low $\quad \infty<0.01$

of the control group was intermediate $(2.44 \pm 0.24$ $\mu \mathrm{mol} / \mathrm{l}, n=20$ ) and did not differ significantly from either of the two verapamil groups.

\section{Kidney Weight and Histology}

The wet weights of the kidney remnants obtained immediately after sacrifice did not differ between the control and the Vera low group (Table 4). In the Vera high group, however, the kidney remnants were generally larger and most of them weighed more than the medians of the two other groups. The difference in kidney size was mainly due to tubulointerstitial changes, with markedly dilated tubular structures filled by proteinaceous cast material (Fig. 3). The mean diameter of non-sclerosed glomeruli did not differ between groups and within-group correlations between mean glomerular diameter and kidney weight were not significant.

The percentage of glomeruli with segmentally or totally sclerosed capillary tufts ranged between $0 \%$ and some $90 \%$ in each of the three groups (Table 4). The median percentage of sclerosed glomeruli was $14 \%$ in the Vera high group, $11 \%$ in the Vera low, and $7 \%$ in the control rats (n.s.). Those rats that did not survive up to the end of the 16 weeks had between $66 \%$ and $92 \%$ segmentally or totally sclerosed glomeruli. As shown in Fig. 4, increasing kidney weights were associated with
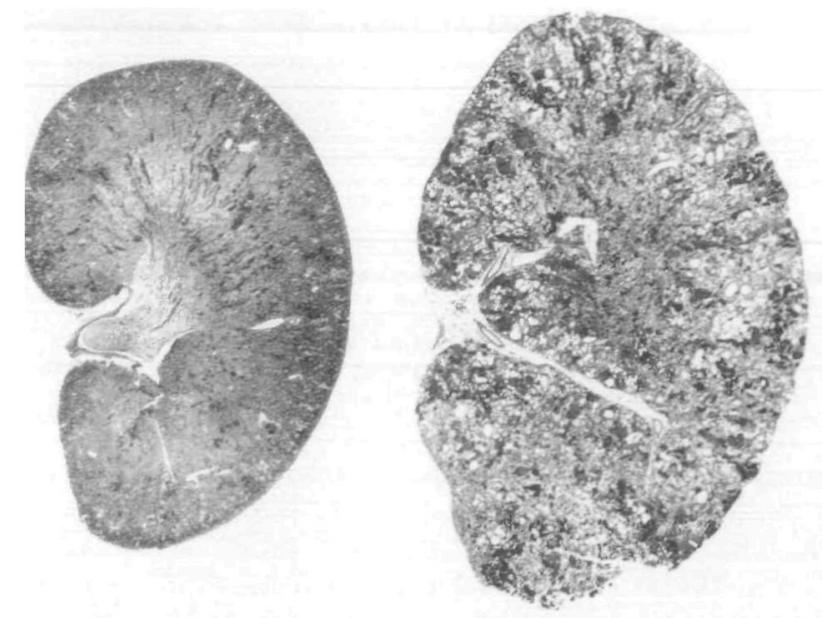

Fig. 3. Whole kidney sections (left) of rat No. 39, control group (systolic blood pressure consistently above $200 \mathrm{mmHg}$, proteinuria increasing from 0.6 to $1.6 \mathrm{mg} / \mu \mathrm{mol} \mathrm{Cr}$ at 16 weeks), and (right) of rat No. 43, Vera high group (systolic blood pressure lowered from above $200 \mathrm{mmHg}$ to $140-155 \mathrm{mmHg}$ at $4-12$ weeks, proteinuria increasing from 1.6 to $11.0 \mathrm{mg} / \mu \mathrm{mol} \mathrm{Cr}$, sacrificed at 13 weeks of treatment). Note enlargement due to dilated tubular structures with darkly staining proteinaceous casts in verapamil kidney $(\times 2.7$; chromotope aniline-blue stain).

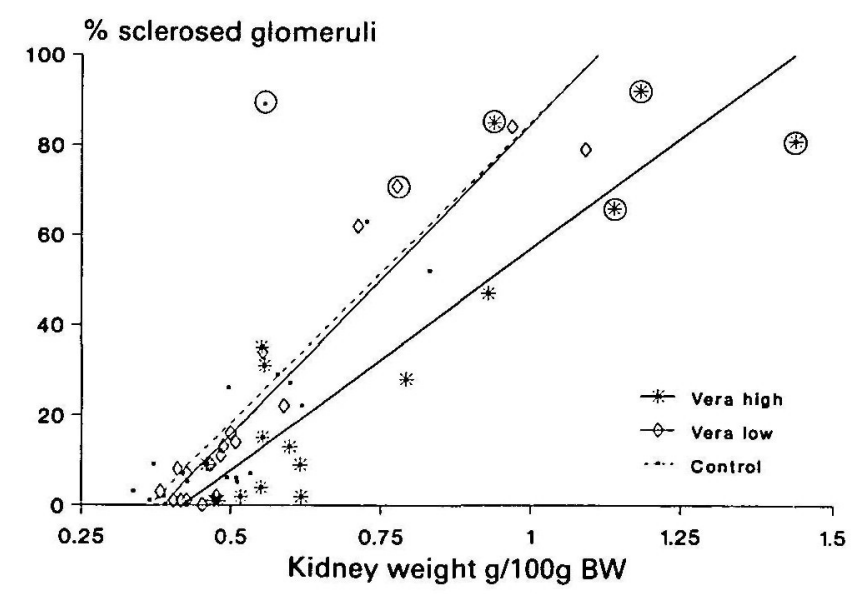

Fig. 4. Proportion of sclerosed glomeruli in relation to kidney wet weight. Animals dying before the end of the 16 weeks experimental period are marked with $O$. The percentage of sclerosed glomeruli and kidney weight are significantly correlated in all three groups (control group Spearman $r=0.766, P<0.002$; group Vera low $r=0.819, P<$ 0.002 ; group Vera high $r=0.814, P<0.002$ ).

Table 4. Remnant kidney weight and histology

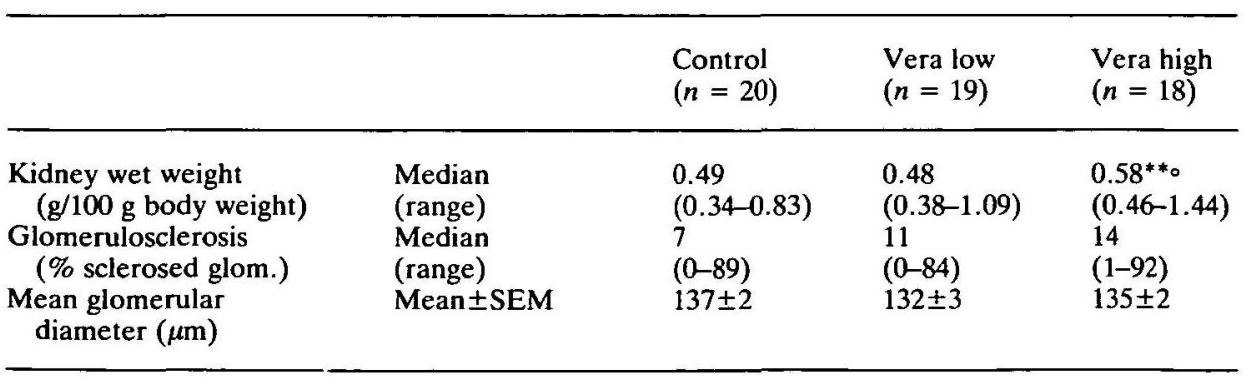

$P$ (Mann-Whitney U-test) vs control ** $<0.01$

Vera high vs Vera low $\circ<0.05$ 
increasing proportions of sclerosed glomeruli (Spear$\operatorname{man} r=0.814$ (Vera high), $r=0.819$ (Vera low), $r=$ 0.766 (control), $P<0.002$ in each group). However, for any degree of glomerulosclerosis, the kidneys generally appeared to be larger in the Vera high group.

The percentage of segmentally or totally sclerosed glomeruli was highly significantly correlated in all groups with final proteinuria (control group Spearman $r$ $=0.870, P<0.002$, Vera low $r=0.888, P<0.002$, Vera high $r=0.915, P<0.002)$ as well as with plasma creatinine concentration at sacrifice (control group $r=$ $0.558, P<0.01$, Vera low $r=0.892, P<0.001$, Vera high $r=0.875, P<0.001)$. Regarding blood pressure, highly significant correlations were obtained between systolic blood pressure in the awake rat before starting treatment and the degree of glomerulosclerosis (control group $r=0.720, P<0.001$, Vera low $r=0.728, P<$ 0.001 , Vera high $r=0.603, P<0.005)$. Similarly, at least for groups Vera low and control, glomerulosclerosis was also significantly correlated with final systolic blood pressure (control group $r=0.703, P<0.001$, Vera low $r=0.459, P<0.05$ for all survivors, $r=0.605$, $P<0.01$ excluding the one uraemic survivor with a plasma urea of $118 \mathrm{mmol} / \mathrm{l})$. However, as a consequence of the antihypertensive efficacy of high-dose verapamil, final systolic blood pressure differed little among rats of the Vera high group and was thus not correlated significantly with glomerulosclerosis $(r=0.298$, n.s. $)$.

\section{Discussion}

The present study demonstrates that effective control of hypertension with verapamil not only failed to protect from progressive renal damage but shortened survival and enhanced proteinuria in a rat remnant kidney model. This confirms our previous observation with relatively high though not reliably antihypertensive dosage of verapamil, which aggravated proteiuria, tended to worsen glomerulosclerosis, and shortened survival in the same rat model [1]. As in this previous study, the higher and now effectively antihypertensive dosage of verapamil was again associated with significantly larger remnant kidneys. The increase in kidney size was also due to tubulointerstitial changes, with massive dilatation of tubules which were filled by proteinaceous casts. The size of the non-sclerosed glomeruli, however, was by no means greater than in control remnants. Remnant kidney enlargement thus appeared not to be due to hypertrophy of viable renal tissue but was probably the consequence of the exaggerated proteinuric response to verapamil treatment with filling of nephrons with proteinaceous cast material.

An adverse effect of calcium channel blockers on the rat remnant kidney has not been found by some other investigators. Harris et al [14] reported improved survival when administering as little as $0.2 \mathrm{mg} / \mathrm{kg}$ bodyweight s. c. in two divided doses in male Munich Wistar rats with renal ablation performed according to almost the same procedure as in the present study. This small amount of verapamil, which is less than $2 \%$ of the dose used in the Vera low group of the present study, failed to have any demonstrable effect on systemic haemodynamics, glomerular filtration rate, renal blood flow, and proteinuria [14, 19]. Protection against progressive chronic renal failure was thought to be due to a peculiar combination of unchanged glomerular capillary hypertension and increased proximal tubular pressure [19]. Histologically, this minute dose of verapamil had no effect on tubular morphology studied at 4 weeks [19] but appeared to prevent or delay uraemic nephrocalcinosis [20]. The two salient differences in experimental design, compared to the present study were the early start of verapamil treatment, which may have affected the period of remnant glomerular hypertrophy during the first 5 weeks after renal ablation, and more importantly the much smaller though parenterally applied dosage.

Unfortunately, precise information on the bioavailability of oral verapamil in the rat is lacking. In humans, some $80 \%$ of oral verapamil is removed by the first-pass effect through the liver. Assuming a similar bioavailability of $20 \%$ for verapamil in the rat, the dose applied by Harris et al [14] would have been ten times smaller than the dose given to the Vera low group and one hundred times smaller than the dose needed to effectively control hypertension in the Vera high group of the present study or in the spontaneously hypertensive rat [16]. At first sight, this dosage may seem excessive compared to the clinical dosage of verapamil needed to control hypertension in humans. However, as shown by Fleckenstein's group [16, 21], the orally effective antihypertensive dosages of a broad selection of calcium channel blocking agents - from nifedipine to diltiazem were found to be 30 to over 100 times greater for the spontaneously hypertensive rat compared to the human. Rather than being toxic, $100-150 \mathrm{mg}$ per $\mathrm{kg}$ verapamil prevented early mortality and prolonged life span of spontaneously hypertensive rats by some $50 \%$ [22].

Whilst Harris et al [14] thus administered their calcium channel blocker in a haemodynamically ineffective dose, Eliahou et al [15] used oral nisoldipine, another calcium channel blocker, in a relatively small dose of $0.3-0.6 \mathrm{mg} / \mathrm{kg}$ per day that was effective initially in preventing and later in attenuating hypertension in male and female rats. In contrast to the present study where initial remnant kidney hypertrophy was allowed to occur undisturbed by drug interference, Eliahou et al started nisoldipine immediately after renal ablation. 
This may suggest that calcium channel blockers exert a protective effect only when started before remnant nephron hypertrophy and the hypertensive state are fully established. It is also intriguing to note that nisoldipine and to a lesser extent hydralazine improved survival though not affecting the heavy proteinuria. The finding of protection against progressive chronic renal failure without an antiproteinuric effect by Eliahou et al [15] as well as by Harris et al [14] is unique. In all other studies of protection afforded by antihypertensive drugs $[1,2,5,11,12]$, by dietary measures such as low-protein diet [23, 24], low-phosphorus diet [25], or polyunsaturated fatty acid supplemented diet [26], or by other drugs such as lipid-lowering agents [27] or heparin [28], the beneficial effect was always associated with decreased proteinuria.

Despite lacking an antiproteinuric effect, calcium channel blockers cannot be denied to be protective, though only when started early after renal injury and in low dosage $[14,15]$. Once remnant hypertrophy and arterial hypertension are established, haemodynamically effective doses of verapamil that control systemic hypertension will no longer be protective, but worsen progressive renal failure, a process that is associated with more rapidly increasing proteinuria.

The mechanisms responsible for progression of renal failure due to glomerulosclerosis have not been fully elucidated. Most prominent are the theories of hyperfiltration [23] and of mesangial overflow with macromolecules or toxic lipoproteins $[29,30]$. The present study does not allow us to draw any conclusions regarding other potentially harmful mechanisms such as simple hyperlipidaemia $[27,31]$ or uraemic nephrocalcinosis [20]: plasma lipids at sacrifice showed unimportant differences between groups and overt nephrocalcinosis was not seen histologically.

Being a potent arteriolar vasodilator, verapamil could accelerate renal failure by exaggerating hyperfiltration due to afferent vasodilatation. Such an effect could be demonstrated by acute experiments in our remnant kidney model. Intravenous verapamil did in fact increase renal blood flow and probably also glomerular capillary pressure, as deduced from an increase in proximal tubular stop flow pressure despite a marked decrease in systemic arterial blood pressure [32]. However, recent observations by Yoshida et al [33] seem to indicate that increased glomerular capillary pressure may be less important than the glomerular hypertrophic response to decreased renal mass. In their hands, tripledrug antihypertensive treatment with hydralazine, reserpine, and hydrochlorothiazide was as effective as enalapril in delaying glomerulosclerosis in strict correlation with retarding glomerular hypertrophy, despite only minor blunting of the increase in glomerular capillary pressure by triple-drug therapy compared to the marked amelioration of glomerular capillary hypertension by enalapril.

Quite recently, fully antihypertensive calcium channel blockade by nifedipine started early after $5 / 6$ nephrectomy has been shown to inhibit glomerular hypertrophy and thereby decrease proteinuria and attenuate glomerulosclerosis in the absence of any effect on glomerular capillary hypertension [34]. One could, therefore, speculate that calcium channel blockers administered early after renal ablation even in haemodynamically ineffective dosage could delay the morphological hypertrophic response and thereby protect against the later development of glomerulosclerosis. In fact, verapamil has been shown to inhibit compensatory hypertrophy after uninephrectomy in rats [35] and an antiproliferative effect of calcium channel blockers has also been described in a variety of in vitro models [ 36 , 37]. However, when the stage is set for progressive glomerulosclerosis by undisturbed hypertrophy during the weeks following renal ablation, no further protection will be afforded by low-dose calcium antagonists, whilst high-dose, antihypertensively effective therapy with such agents might adversely affect glomerular capillary walls or increase mesangial flooding by macromolecules as indicated by the enhanced proteinuria.

In contrast to the human kidney, which shrinks with chronic progressive renal failure, the failing rat remnant kidney increases in size [1]. This is correlated with the degree of proteinuria and appears to result from the deposition of proteinaceous cast material in dilated tubular structures $[1,38]$. The present study shows effective antihypertensive treatment with verapamil to increase the proteinuria as well as the size of the more rapidly failing remnant kidneys. This is yet another discrepancy between the rat remnant kidney model and chronic progressive renal failure in the human. Nevertheless, it is tempting to extrapolate from these findings in the remnant kidney rat to the patient with chronic renal disease. Thus, antihypertensive regimens that decrease proteinuria might be superior to those that do not affect or even worsen proteinuria, as seems to be the case for some calcium channel blockers [39]

Acknowledgements. This study was supported by Swiss Nationa Science Foundation Grant No. 3897-0.83. Verapamil was supplied by Knoll AG, Germany. The technical assistance of S. Zurbrügg and J. Violante, and the secretarial skills of Miss E. Graf are gratefully acknowledged.

\section{References}

1. Brunner FP, Thiel G, Hermle M, Bock HA, Mihatsch MJ. Long term enalapril and verapamil in rats with reduced renal mass. Kidney Int 1989; 36: 969-977

2. El Nahas AM. Glomerulosclerosis: Insights into pathogenesis and treatment. Nephrol Dial Transplant 1989; 4: 843-853

3. Anderson S, Meyer TW, Rennke HG, Brenner BM. Control of 
glomerular hypertension limits glomerular injury in rats with reduced renal mass. J Clin Invest 1985; 76: 612-619

4. Anderson S, Rennke HG, Garica DL, Brenner BM. Short and long term effects of antihypertensive therapy in the diabetic rat Kidney Int 1989; 36: 526-536

5. Dworkin LD, Feiner HD, Randazzo J. Glomerular hypertension and injury in desoxycorticosterone-salt rats on antihypertensive therapy. Kidney Int 1987; 31: 718-724

6. Marinides GN, Groggel GC, Cohen AH, Border AW. Enalapril and low protein reverse chronic puromycin aminonucleoside nephropathy. Kidney Int 1990; 37: 749-757

7. Parving $\mathrm{HH}$, Andersen AR, Smidt UM, Hommel E, Mathiesen ER, Svendsen PA. Effect of antihypertensive treatment on kidney function in diabetic nephropathy. Br Med J 1987; 294 1443-1447

8. Björck S, Nyberg G, Mulec H, Granerus G, Herlitz H, Aurell M. Beneficial effects of angiotensin converting enzyme inhibition on renal function in patients with diabetic nephropathy. $\mathrm{Br} \mathrm{Med} \mathrm{J}$ 1986; 293: 471-474

9. Bergström J, Alvestrand A, Bucht $\mathrm{H}$, Gutierrez A. Progression of chronic renal failure in man is retarded with more frequent clinical follow-ups and better blood pressure control. Clin Nephrol 1985; 25: $1-6$

10. Ruilope LM, Miranda B, Morales JM et al. Converting enzyme inhibition in chronic renal failure. Am J Kidney Dis 1989; 2: 120126

11. Mann J, Ritz E. Preservation of kidney function by use of converting enzyme inhibitors for control of hypertension. Lancet 1987; 2: 622

12. Anderson S, Rennke HG, Brenner BM. Therapeutic advantage of converting enzyme inhibitors in arresting progressive renal disease associated with systemic hypertension. J Clin Invest 1986 77: 1993-2000

13. Jackson B, Debrevi L, Cubela R, Whitty M, Johnston CI Preservation of renal function in the rat remnant kidney model of chronic renal failure by blood pressure reduction. Clin Exp Pharmacol Physiol 1986; 13: 319-323

14. Harris DCH, Hammond WS, Burke TJ, Schrier RW. Verapamil protects against progression of chronic renal failure. Kidney Int 1987; 31: 41-46

15. Eliahou HE, Cohen D, Herzog D et al. The control of hypertension and its effect on renal function in rat remnant kidney. Nephrol Dial Transplant 1988; 3: 38-44

16. Von Witzleben H, Frey M, Keidel J, Fleckenstein A. Normalization of blood pressure in spontaneously hypertensive rats by long-term oral treatment with verapamil and nifedipine. Pflügers Arch S R9: 1980; 384 (A)

17. Dormas BT, Watson WA, Biggs HG. Albumin standards and the measurement of serum albumin with bromcresol green. Clin Chim Acta 1971; 31: 87-96

18. Yatzidis $\mathbf{H}$. New colorimetric method for quantitative determination of protein in urine. Clin Chem 1977; 23: 811-812

19. Pelayo JC, Harris DCH, Shanley PF, Miller GJ, Schrier RW. Glomerular hemodynamic adaptations in remnant nephrons: effects of verapamil. Am J Physiol 1988; 254: F425-F431

20. Goligorsky MS, Chaimovitz C, Rapoport J, Goldstein J, Kol R. Calcium metabolism in uremic nephrocalcinosis: Preventive effect of verapamil. Kidney Int 1985; 27: 774-779

21. Fleckenstein A, Frey M, Zorn J, Fleckenstein-Grün G. Interdependence of antihypertensive, anticalcinotic, and antiarteriosclerotic effects of calcium antagonists - model experiments on spontaneously hypertensive rats (SHR). Bayer-Symposium IX.
Cardiovascular Effects of Dihydropyridine-Type Calcium Antagonists and Agonists, Springer-Verlag, Berlin, Heidelberg 1985: 480-499

22. Raschack M, Gries J, Kirchengast M, Bühler V. Chronic oral verapamil prevents progression of hypertension and prolongs lifespan in spontaneously hypertensive rats. In: Fleckenstein A, Laragh JH, eds. Hypertension - The Next Decade: Verapamil in Focus. Churchill Livingstone, Edinburgh, London, Melbourne, New York 1987: 302-306

23. Hostetter TH, Olson JL, Rennke HG et al. Hyperfiltration in remnant nephrons; a potentially adverse response to renal ablation. Am J Physiol 1981; 241: F85-F93

24. El Nahas AM, Paraskevakou H, Zoob S et al. Effect of dietary protein restriction on the development of renal failure after subtotal nephrectomy in rats. Clin Sci 1983; 32: 83-87

25. Ibels LS, Alfrey AC, Haut L, Huffer WE. Preservation of function in experimental renal disease by dietary phosphate restriction. N Engl J Med 1978; 298: 122-126

26. Heifets M, Morrissey JJ, Purkerson ML et al. Effect of dietary lipids on renal function in rats with subtotal nephrectomy. Kidney Int 1987; 32: 335-341

27. Kasiske BL, O'Donnell MP, Garvis WJ, Keane WF. Pharmacologic treatment of hyperlipidemia reduces glomerular injury in the rat 5/6 nephrectomy model of chronic renal failure. Circ Res 1988; 62: $367-374$

28. Olson $\mathrm{JL}$. The role of heparin as a protective agent following reduction of renal mass. Kidney Int $1984 ; 25: 376-382$

29. Velosa JA, Glasser RJ, Nevins TE, Michael AF. Experimental model of focal sclerosis. II. Correlation with immunopathologic changes, macromolecular kinetics, and polyanion loss. Lab Invest 1977; 29: 527-534

30. Grond J, Koudstaal J, Elema JD. Mesangial function and glomerular sclerosis in rats with aminonucleoside nephrosis. Kidney Int 1985; 27: 405-410

31. Moorhead JF, El Nahas M, Chan MK, Varghese Z. Lipid nephrotoxicity in chronic progressive glomerular and tubulointerstitial disease. Lancet 1982; 2: 1309-1311

32. Brunner FP, Hermle M, Thiel G. Verapamil (V) in contrast to enalapril (E) aggravates hyperfiltration despite lowered bloodpressure in rats with reduced renal mass. Xth International Congress of Nephrology. The Alden Press, Oxford 1987; 497 (A)

33. Yoshida Y, Kawamura T, Ikoma M, Fogo A, Ichikawa I Effect of antihypertensive drugs on glomerular morphology. Kidney Int 1989; 36: 626-635

34. Dworkin LD, Parker M, Feiner HD Nifedipine decreases glomerular injury in rats with remnant kidneys by inhibiting glomerular hypertrophy. J Amer Soc Nephrol 1990; 4: 427 (A)

35. Jobin JR, Bonjour JP. Compensatory renal growth: modulation by calcium PTH and 1,25-(OH)${ }_{2}$ D3. Kidney Int 1986; 29: 1124 1130

36. Jackson CL, Bush RC, Bowyer DE. Inhibitory effect of calcium antagonists on balloon catheter-induced arterial smooth muscle cell proliferation and lesion size. Atherosclerosis 1988; 69: 115-122

37. Grier CE, Mastro AM. Mitogen and co-mitogen stimulation of lymphocytes inhibited by three $\mathrm{Ca}^{++}$antagonists. $J$ Cell Physiol 1985; 124: 131-136

38. Kenner CH, Evans AP, Blomgren P, Aronoff GR, Luft FC. Effect of protein intake on renal function and structure in partially nephrectomized rats. Kidney Int 1985; 27: 739-750

39. Mickisch $O$, Schmid M, Mann JFE et al. Calciumantagonisten bei chronischer Niereninsuffizienz. Dtsch Med Wochenschr 1988 113: $1546-1548$ 